\title{
Gambaran Glukosa Darah Setelah Latihan Fisik pada Tikus Wistar Diabetes Melitus yang Diinduksi Aloksan
}

\author{
Ahmad Syukri Harahap ${ }^{1}$, Rahmatina B. Herman², Eti Yerizel ${ }^{3}$
}

\begin{abstract}
Abstrak
Diabetes Melitus telah dikategorikan sebagai penyakit global yang prevalensinya terus meningkat dan penyebab utama morbiditas dan mortalitas. Latihan fisik merupakan salah satu tatalaksana untuk mengontrol glukosa darah secara nonfarmakologis. Tujuan dari penelitian ini adalah untuk mengetahui gambaran kadar glukosa darah pada tikus Wistar diabetes melitus yang diinduksi aloksan setelah pemberian latihan fisik. Penelitian eksperimental ini menggunakan 18 ekor tikus Wistar dengan berat badan 150-200 gram yang dibagi menjadi tiga kelompok, yaitu 6 ekor kelompok kontrol negatif $(\mathrm{K}-), 6$ ekor kelompok kontrol positif $(\mathrm{K}+)$ dengan induksi aloksan tanpa pemberian latihan fisik dan 6 ekor kelompok perlakuan $(P)$ dengan induksi aloksan dan diberi latihan fisik selama 4 minggu. Pengukuran kadar glukosa darah dilakukan dengan glucometer merek Accu-Check. Hasil penelitian menunjukkan peningkatan rata-rata kadar glukosa darah puasa secara bermakna pada kelompok kontrol positif $(K+)$ dan perlakuan $(P)$ setelah periode induksi yaitu, pada kelompok kontrol negatif $84,83 \pm 6,88 \mathrm{mg} / \mathrm{dl}$, kelompok kontrol positif 220,80 $\pm 12,29 \mathrm{mg} / \mathrm{dl}$, dan kelompok perlakuan $248,50 \pm 94,55 \mathrm{mg} / \mathrm{dl}(\mathrm{p}<0,05)$. Setelah periode latihan fisik, terdapat penurunan rata-rata glukosa darah puasa secara bermakna pada kelompok kontrol positif $\left(K_{+}\right)$dan Perlakuan $(P)$, namun penurunan pada kelompok perlakuan $(\mathrm{P})$ lebih besar secara bermakna dibandingkan dengan kelompok kontrol positif $(\mathrm{K}+)$, yaitu rata-

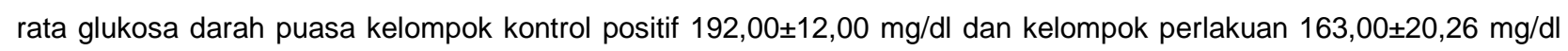
$(p<0,05)$. Kesimpulan hasil penelitian ini adalah terdapat penurunan kadar glukosa darah puasa setelah latihan fisik.
\end{abstract}

Kata kunci: latihan fisik, glukosa darah, diabetes melitus

\section{Abstract}

Diabetes Melitus has been categorized as a global disease which have increasing prevalence and the mine cause of morbidity and mortality. Phyisical exercise is one of the nonpharmacological treatment to control blood glucose. The objective of this research was to determine the blood gucose levels of aloksan induced's wistar rat after physical exercise. The research used 18 wistar rats 150-200 gram weight, divided into three groups, as six negative control group (K-), six positive control group inducing aloksan without physical exercise (K+) and six treated group inducing aloksan with physical exercise for four weeks $(P)$. Blood glucose was measured by Accu Check's glucometer. The result showed an increase in fasting blood glucose level significantly on positive control group (K-) and treated group $(P)$ after induced period, which was $84,83 \pm 6,88 \mathrm{mg} / \mathrm{dl}$ on negative control group, 220,80 $\pm 12,29 \mathrm{mg} / \mathrm{dl}$ on positive control group, and $248,50 \pm 94,55 \mathrm{mg} / \mathrm{dl}$ on treated group $(p<0,05)$. After physical exercise period, there was a decrease in fasting blood significantly on $K+$ and $P$, but in $P$ group have more greater than $K+$ group, 192,00 $\pm 12,00$ $\mathrm{mg} / \mathrm{dl}$ on positive control group $(K+)$ and $163,00 \pm 20,26 \mathrm{mg} / \mathrm{dl}$ on treated group $(P)$. Conclusion of this research is a decrease in fasting blood glucose levels after phyisical exercise.

Keywords: physical exercise, blood glucose, diabetes melitus

Affiliasi penulis : 1. Pendidikan Dokter FK UNAND (Fakultas Kedokteran Universitas Andalas), 2. Bagian Fisiologi FK UNAND, 3. Bagian Biokimia FK UNAND

Korespondensi :Ahmad Syukri Harahap, E-mail: harahap.soleh@gmail.com, telp: 085376177456

\section{PENDAHULUAN}

Diabetes Melitus (DM) adalah salah satu penyakit degeneratif yang jumlah penderitanya terus meningkat dari tahun ke tahun. Menurut WHO ditahun 
2005, DM menduduki peringkat ketujuh dari total kematian akibat penyakit tidak menular. DM juga dinilai sebagai salah satu penyakit kronis yang paling sering ditemukan pada abad ke-21 ini. ${ }^{1}$

DM telah dikategorikan sebagai penyakit global dengan prevalensi telah lebih dari dua kali lipat selama tiga dekade terakhir. Hampir satu dari sepuluh orang dewasa di seluruh dunia terkena DM. Selain itu, DM juga dianggap sebagai penyebab utama morbiditas dan mortalitas. Pada tahun 2011, International Diabetes Federation (IDF) menyatakan bahwa 366 juta orang di dunia menderita DM dan diperkirakan akan meningkat menjadi 552 juta jiwa pada tahun 2030 . $^{2,3}$

Prevalensi diabetes yang tinggi, khususnya pada usia dewasa berdampak terhadap tingginya biaya perawatan yang harus dikeluarkan. Pada tahun 2007 di Amerika, diabetes dan prediabetes menimbulkan kerugian sebesar 218 juta dolar baik karena biaya perawatan maupun kerugian karena kehilangan produktivitas penduduk yang menderita diabetes. $^{4}$

Diabetes melitus menyebabkan kematian dini yang cukup banyak. Sebuah situasi yang cenderung memburuk, khususnya di negara berpenghasilan rendah dan menengah. DM menyebabkan $6 \%$ dari total kematian usia dewasa di Afrika dan 15,7\% di Amerika Utara. Pada seluruh bagian wilayah ditemukan proporsi kematian lebih tinggi pada wanita dibandingkan pria setelah berusia 49 tahun. ${ }^{5}$

Penyakit DM menduduki urutan nomor empat dari prioritas penelitian nasional untuk penyakit degeneratif setelah penyakit kardiovaskuler dan serebrovaskuler. Departemen Kesehatan menyatakan bahwa penderita DM semakin meningkat. WHO memprediksi kenaikan jumlah penderita DM di Indonesia dari 8,4 juta pada tahun 2000 menjadi sekitar 21,3 juta pada tahun 2030. Pada tahun 2009, International Diabetes Federation (IDF) juga memprediksi kenaikan jumlah penderita DM dari 7,0 juta pada tahun 2009 menjadi 12 juta pada tahun 2030. Meskipun terdapat perbedaan angka prevalensi, laporan keduanya menunjukkan adanya peningkatan jumlah penderita DM sebanyak 2-3 kali lipat. ${ }^{6}$

Berdasarkan data dari Dinas Kesehatan Kota Padang, pada tahun 2011 DM merupakan penyakit ketiga terbanyak yang dirujuk dari puskesmas Kota Padang dengan jumlah 4.084 orang. Pada tahun 2011 DM berada di posisi kedua penyebab kematian terbanyak di kota Padang sebesar 79 kasus $(17,4 \%){ }^{7}$

Sampai saat ini belum ada cara untuk menghilangkan atau menyembuhkan DM. Hal yang dapat kita lakukan adalah menghindari berbagai faktor resiko untuk terjadinya DM. Apabila DM telah terjadi, maka kadar glukosa darah harus dikendalikan, sehingga kemungkinan timbulnya berbagai komplikasi dapat dicegah. ${ }^{8}$

Langkah pertama yang harus dilakukan dalam penatalaksanaan DM adalah penatalaksanaan secara nonfarmakologis, berupa pengaturan diet dan latihan fisik. Dengan latihan fisik, sejumlah kalori tertentu akan dibakar, dengan demikian kelebihan kalori tubuh dapat diperkecil. Dengan latihan fisik, tingkat penggunaan glukosa oleh sel tubuh akan menjadi lebih baik. ${ }^{8}$

Berdasarkan uraian di atas, perlu dilakukan penelitian untuk mengetahui gambaran kadar glukosa darah pada penderita DM setelah latihan fisik. Penelitian ini akan dilakukan pada tikus Wistar, karena karakter fisiologinya yang diketahui mirip dengan manusia dan mudah dipelihara.

Tujuan penelitian ini adalah untuk mengetahui gambaran kadar glukosa darah pada tikus Wistar diabetes melitus yang diinduksi aloksan setelah pemberian latihan fisik. Khususnya, penelitian ini bertujuan untuk mengetahui gambaran kadar glukosa darah pada tikus Wistar normal, glukosa darah tikus Wistar DM yang diinduksi aloksan dan glukosa darah pada tikus Wistar DM setelah diberikan latihan fisik.

\section{METODE}

Jenis penelitian adalah eksperimental dengan rancangan randomized pre and post test only control group design untuk mengetahui gambaran kadar glukosa darah pada tikus Wistar DM yang diinduksi aloksan setelah latihan fisik. Subjek penelitian adalah tikus putih (Rattus norvegicus) jantan Strain Wistar.

Jumlah tikus yang dipakai sebagai subjek sesuai dengan kriteria WHO, yaitu minimal lima (5) ekor tikus pada setiap kelompok. ${ }^{9}$ Subjek penelitian adalah 16 ekor tikus Wistar, yang dibagi menjadi tiga kelompok, yaitu Kelompok K- sebagai kelompok 
kontrol negatif, Kelompok $\mathrm{K}+$ sebagai kelompok kontrol positif, dan Kelompok $\mathrm{P}$ sebagai kelompok perlakuan. Kelompok K- tidak diberi perlakuan, kelompok $\mathrm{K}+$ diinduksi aloksan dan kelompok $\mathrm{P}$ diinduksi aloksan dan diberi latihan fisik. Pemilihan sampel dan pengelompokkannya dilakukan secara acak.

Kriteria inklusi adalah tikus Wistar jantan sehat, berumur 2-3 bulan pada saat pemilihan sampel dengan berat badan 150-250 gram dan dalam keadaan diabetes setelah dinduksi aloksan. Kriteria eksklusi adalah tikus Wistar sakit.

Variabel independen penelitian adalah pemberian latihan fisik selama 4 minggu. variabel dependen adalah kadar glukosa darah yang diukur dengan glucometer merk Accu-Check.

Aklimatisasi terhadap hewan dilakukan selama 7 hari untuk membiasakan hewan pada kondisi percobaan dan diberi makanan standar serta minuman yang cukup. Setiap kelompok diberikan makanan yang sama. Pada saat akhir aklimatisasi dilakukan pemeriksaan kadar glukosa darah puasa pada hewan percobaan.

Kelompok $\mathrm{K}+$ dan $\mathrm{P}$ kemudian diinduksi aloksan dengan dosis $150 \mathrm{mg} / \mathrm{kgBB}$ secara intraperitoneal. Setelah tiga hari, dilakukan pemeriksaan kadar glukosa darah puasa untuk mengetahui apakah tikus telah mengalami keadaan diabetes melitus ( $\geq 150 \mathrm{mg} / \mathrm{dl}) .{ }^{10}$

Setelah tikus mengalami diabetes melitus, kelompok $\mathrm{P}$ diberi latihan fisik yaitu berenang dengan lama 30 menit, frekuensi $4 x$ dalam seminggu selama 4 minggu. ${ }^{11}$

Setelah empat minggu perlakuan, masing masing kelompok dilakukan pengukuran kadar glukosa darah puasa. Sebelum pengukuran, tikus dipuasakan selama 8-12 jam. Selanjutnya darah diambil dari vena ekor tikus.

Hasil pengukuran kadar glukosa darah puasa tikus dicatat, ditabulasi dan dianalisis secara statistik menggunakan program SPSS. Analisis data terhadap perubahan kadar glukosa darah puasa dilakukan melalui uji One-Way ANOVA dan Repeated ANOVA.
Nilai yang didapat ditampilkan dalam bentuk Rerata (mean) dan simpangan baku (standard deviation) untuk tiap kelompok dihitung dari data yang didapatkan.

\section{HASIL}

Hewan percobaan adalah 18 ekor tikus Wistar jantan berumur 2-3 bulan dengan berat badan 150-200 gram yang dibagi atas 3 kelompok, yaitu 6 ekor kelompok kontrol negatif (K-), 6 ekor kelompok kontrol positif $(\mathrm{K}+)$ dengan induksi aloksan tanpa pemberian latihan fisik dan 6 ekor kelompok perlakuan (P) dengan induksi aloksan dan pemberian latihan fisik selama 4 minggu.

Beberapa hari setelah induksi aloksan terdapat 1 tikus wistar yang mati pada kelompok kontrol positif $(\mathrm{K}+)$. Kemudian pada saat periode latihan fisik terdapat 1 ekor tikus wistar yang mati pada kelompok perlakuan (P). Sehingga pada akhir penelitian terdapat 6 ekor kelompok kontrol negatif, dan masing-masingnya 5 ekor dalam kelompok kontrol positif dan perlakuan.

Pada Tabel 1 terlihat bahwa berat badan hewan percobaan tidak berbeda secara bermakna $(p>0,05)$.

Tabel 1. Berat Badan Hewan Percobaan

\begin{tabular}{lccc}
\hline \multicolumn{1}{c}{ Kelompok } & N & Berat Badan (gr) & $P$ \\
\hline Kontrol Negatif & 6 & $166,50 \pm 5,05$ & \\
Kontrol Positif & 6 & $163,67 \pm 3,20$ & 0,601 \\
Perlakuan & 6 & $165,50 \pm 5,90$ & \\
\hline \multicolumn{4}{l}{ Data disajikan dalam bentuk Mean $\pm \mathrm{SD}$}
\end{tabular}

Pengukuran kadar glukosa darah pada hewan percobaan dilakukan setelah akhir aklimatisasi, setelah periode induksi aloksan dan setelah periode latihan fisik selama 4 minggu. Pada Tabel 2 berikut ini dapat dilihat perubahan glukosa darah puasa dari ketiga pengukuran pada masing-masing kelompok hewan percobaan.

Uji repeated ANOVA menunjukkan bahwa kelompok kontrol negatif (K-) tidak terdapat perbedaan yang bermakna pada ketiga pengukuran ( $p>0,05)$. 
Pada kelompok kontrol positif $(\mathrm{K}+)$, didapatkan $p<0,05$, artinya paling tidak terdapat dua pengukuran yang berbeda. Pada uji post-hoc paired wise comparasion diperoleh perbedaan yang bermakna antara kadar glukosa darah puasa pd saat akhir aklimatisasi dan setelah induksi aloksan. Kemudian pada kelompok kontrol positif juga didapatkan perbedaan glukosa darah puasa yang bermakna antara setelah diinduksi aloksan dengan setelah periode latihan fisik.

Tabel 2. Perbandingan Glukosa Darah Puasa Hewan Percobaan Saat Akhir Aklimatisasi, Setelah Periode Induksi Aloksan dan Setelah Periode Latihan Fisik

\begin{tabular}{lcccc}
\hline Kelompok & $\begin{array}{c}\text { GDP Akhir Aklimatisasi } \\
\text { (GDP 1) }\end{array}$ & $\begin{array}{c}\text { GDP Setelah Periode } \\
\text { Induksi Aloksan (GDP 2) }\end{array}$ & $\begin{array}{c}\text { GDP Setelah Periode } \\
\text { Latihan Fisik (GDP 3) }\end{array}$ & $P$ \\
\hline K- & $89,00 \pm 7,53$ & $84,83 \pm 6,88$ & $82,00 \pm 6,60$ & 0,347 \\
K+ & $83,67 \pm 9,67$ & $220,80 \pm 12,29$ & $192,00 \pm 12,00$ & 0,001 \\
P & $88,83 \pm 5,56$ & $248,50 \pm 94,55$ & $163,00 \pm 20,26$ & 0,002 \\
\hline
\end{tabular}

UJi repeated anova kelompok K-. Uji post-hoc paired wise comparasion: GDP 1vs GDP 2 p = 0,486; GDP 1vs GDP 3 p= 0,122;

GDP 2 vs GDP $3 p=0,590$

UJi repeated anova kelompok $\mathrm{K}+$. Uji post-hoc paired wise comparasion: GDP 1vs GDP $2 \mathrm{p}=0,000 ;$ GDP $1 \mathrm{vs}$ GDP $3 \mathrm{p}=0,000$; GDP 2 vs GDP $3 p=0,017$

UJi repeated anova kelompok P. Uji post-hoc paired wise comparasion: GDP 1vs GDP $2 \mathrm{p}=0,000$; GDP 1 vs GDP $3 p=0,003$; GDP 2 vs GDP $3 p=0,000$

Pada kelompok perlakuan (P) didapatkan $p<0,05$, artinya paling tidak terdapat dua pengukuran yang berbeda secara bermakna. Pada uji post-hoc diperoleh perbedaan yang bermakna antara glukosa darah puasa saat akhir aklimatisasi dan setelah induksi aloksan. Pada kelompok perlakuan juga didapatkan perbedaan glukosa darah puasa yang bermakna antara glukosa darah puasa setelah diinduksi aloksan dengan setelah latihan fisik selama 4 minggu.

Perbandingan glukosa darah puasa setelah periode induksi aloksan dan setelah periode latihan fisik disajikan pada Tabel 3, yaitu didapatkan perbedaan glukosa darah puasa setelah periode induksi aloksan pada kelompok $\mathrm{K}-, \mathrm{K}+$ dan $\mathrm{P}$ dengan $\mathrm{p}<0,05$. Uji post hoc menunjukkan hasil adanya perbedaan yang bermakna antara kelompok yang diinduksi aloksan $(\mathrm{K}+$ dan $\mathrm{P})$ dengan kelompok yang tidak diinduksi aloksan (K-). Pada kelompok yang diinduksi aloksan yaitu kelompok $\mathrm{K}+$ dan $\mathrm{P}$ tidak terdapat perbedaan yang bermakna.

Analisis data dengan one way ANOVA, didapatkan perbedaan glukosa darah puasa pada ketiga kelompok setelah periode latihan fisik dengan $\mathrm{p}<0,05$. Hasil uji post hoc didapatkan perbedaan yang bermakna antara kelompok kontrol negatif dengan kontrol positif dan adanya perbedaan yang bermakna antara kelompok kontrol negatif dengan kelompok perlakuan. Uji post hoc juga menunjukkan adanya perbedaan yang bermakna antara kelompok kontrol positif dengan kelompok perlakuan yang diberikan latihan fisik selama 4 minggu.

Tabel 3. Perbandingan Glukosa Darah Puasa Hewan Percobaan Setelah Periode Induksi Aloksan dan Setelah Periode Latihan Fisik

\begin{tabular}{lcccc}
\hline & K- & K+ & P \\
\hline GDP Setelah Periode Induksi Aloksan & $84,83 \pm 6,88$ & $220,80 \pm 12,29$ & $248,50 \pm 94,55$ & 0,000 \\
GDP Setelah Periode Latihan Fisik & $82,00 \pm 6,60$ & $192,00 \pm 12,00$ & $163,00 \pm 20,26$ & 0,000 \\
\hline
\end{tabular}

UJi one way anova GDP setelah induksi aloksan. Uji post-hoc LSD: K- vs $\mathrm{K}+\mathrm{p}=0,00 ; \mathrm{K}-\mathrm{vs} \mathrm{P} \mathrm{p}=0,00 ; \mathrm{K}+\mathrm{vs} \mathrm{P} \mathrm{p}=0,647$

UJi one way anova GDP setelah latihan fisik. Uji post-hoc LSD: K-vs $K+p=0,00 ; K$ - vs $P p=0,00 ; K+v s P p=0,012$ 


\section{PEMBAHASAN}

Pada penelitian ini didapatkan hasil kadar glukosa darah puasa pada kelompok kontrol positif $(\mathrm{K}+)$ dan kelompok perlakuan $(\mathrm{P})$ lebih tinggi daripada kelompok kontrol negatif (K-). Hasil penelitian ini menunjukkan bahwa penyuntikan aloksan $150 \mathrm{mg} / \mathrm{kg}$ BB secara intraperitoneal mengakibatkan peningkatan kadar glukosa darah puasa yang bermakna pada tikus wistar. Hasil ini sesuai dengan penelitian sebelumnya bahwa induksi aloksan dapat mengakibatkan diabetes melitus pada tikus wistar. ${ }^{10}$

Menurut Arulmozhi dkk, ada beberapa cara yang bisa digunakan untuk mendapatkan kondisi diabetes pada hewan coba, antara lain: destruksi sel beta secara kimia, pembedahan sebagian dari sel beta, pemberian diet tinggi lemak dan gula, peningkatan pajanan sel dengan hiperinsulinemia, dan pemberian dosis tinggi hormon glukokortikoid. Aloksan adalah suatu senyawa kimia yang sering digunakan untuk penelitian diabetes pada hewan coba. Aloksan bersifat toksik selektif terhadap sel beta pankreas yang memproduksi insulin. Dalam waktu 24-48 jam setelah pemberian aloksan, integritas sel-sel beta menghilang dan terjadi degranulasi yang menyebabkan terjadinya kondisi hiperglikemia yang permanen. Secara morfologi terjadi destruksi dan nekrosis pada sel beta pankreas yang irreversible. ${ }^{12}$

Pada Tabel 2 terlihat rerata glukosa darah puasa kontrol positif mengalami penurunan yang bermakna. Penurunan kadar glukosa darah pada hewan coba yang diinduksi aloksan dapat terjadi karena sel beta pankreas memiliki kemampuan untuk berregenerasi.Penelitian yang dilakukanoleh Erwin et al pada hewan coba model diabetes, didapatkan peningkatan signifikan ekspresi sel beta langerhans pankreas yang imunoreaktif terhadap insulin pada hari ke-28. Menurutnya, ekspresi sel beta pankreas kembali meningkat akibat regenerasi sel beta langerhans pankreas. ${ }^{13}$

Tabel 3 memperlihatkan hasil bahwa terdapat penurunan kadar glukosa darah puasa pada tikus yang diberikan latihan fisik selama 4 minggu, frekuensi 4 kali seminggu dan lama 30 menit dalam satu sesi. Pada saat latihan fisik terjadi peningkatan kebutuhan bahan bakar tubuh oleh otot yang aktif. Pada saat latihan, otot-otot yang aktif menggunakan sejumlah besar glukosa. Penggunaan glukosa yang besar ini tidak membutuhkan sejumlah besar insulin, karena serabut otot yang bekerja menjadi permeabel terhadap glukosa bahkan tanpa adanya insulin akibat proses kontraksi itu sendiri. Sedangkan pada jaringan otot dengan keadaan istirahat membutuhkan insulin untuk mengambil glukosa dari darah. ${ }^{14}$

Menurut Schauer, resistensi insulin tidak hanya menjadi penyebab penting terjadinya DM tipe 2 , melainkan juga terjadi resistensi insulin pada penderita DM tipe 1. Pasien DM tipe 1 memiliki sinyal insulin yang lebih lemah dibandingkan bukan penderita DM. Pada penderita DM tipe 1 dan tipe 2, latihan fisik dapat meningkatkan kontrol glikemik melalui peningkatkan sensitivitas insulin hati dan perifer, penyerapan glukosa, dan kesehatan jantung. ${ }^{15}$

Pada saat berolahraga terjadi peningkatan kepekaan reseptor insulin di otot dan penambahan jumlah insulin reseptor insulin yang aktif. Pada saat berolahraga blood flow meningkat, ini menyebabkan banyak jala-jala kapiler yang terbuka sehingga lebih banyak reseptor insulin yang tersedia dan aktif. Olahraga dapat mengatur gula darah melalui tiga mekanisme berbeda, yaitu: (1) perangsangan akut transport glukosa otot, (2) penguatan akut kerja insulin, dan (3) up-regulation jangka panjang jalur pengisyaratan insulin (insulin signaling) akibat latihan fisik secara teratur. ${ }^{14}$

Pada DM tipe 1 ada dua cara dimana latihan fisik memiliki efek langsung pada regulasi glukosa darah, yaitu sekresi insulin di pankreas dan penyerapan glukosa oleh kontraksi otot rangka. Penelitian Farmer yang menggunakan hewan model diabetes melitus, latihan tidak berpengaruh pada jumlah atau ukuran dari pulau pankreas yang tersisa. Juga tidak terdapat efek pada komposisi sel, baik presentasi sel alfa, beta, dan delta, setelah pemberian latihan fisik. Namun, efek dari latihan fisik selama 6 minggu dapat merangsang produksi insulin, dimana sekresi insulin per sel beta ditingkatkan lebih banyak. $^{16,17}$

Pada penelitian hewan coba model diabetes melitus tipe 1, latihan fisik dapat memelihara sel-sel beta pankreas. Latihan fisik memiliki efek antiinflamasi, sehingga dapat memodulasi proses autoimun pada pula Langerhans. Pada tikus model 
diabetes yang diberikan latihan fisik selama 8 minggu dapat meningkatkan massa sel beta pankreas sebesar $31 \%$. Program satu minggu latihan meningkatkan fungsi sel beta sebesar $27 \%$ pada orang tua dengan gangguan toleransi glukosa. Program latihan delapan bulan pada orang gemuk dewasa meningkatkan $60 \%$ fungsi sel beta. ${ }^{18}$

Penelitian ini juga didukung oleh penelitian Zeqiri, dimana terjadi penurunan kadar glukosa darah yang bermakna pada penderita DM tipe 1 maupun tipe 2 setelah pemberian latihan fisik selama 10 hari. Latihan fisik pada DM tipe 1 dapat meningkatkan sensitivitas insulin, sehingga perlu dilakukan pengurangan dosis insulin untuk menghindari terjadinya hipoglikemia setelah melakukan latihan fisik. $^{19}$

Berbeda dengan hasil penelitian Hadiyanti dkk yang mendapatkan bahwa tidak ada perbedaan kadar glukosa darah yang signifikan antara kelompok tikus wistar model diabetes melitus dengan kelompok tikus diabetes yang diberikan aktivitas fisik isometrik. Menurutnya, aktivitas tunggal yang diberikan menimbulkan stres fisiologis yang dapat menjadi sumber peningkatan kadar glukosa darah. ${ }^{20}$

\section{KESIMPULAN}

Berdasarkan hasil penelitian didapatkan kesimpulan bahwa kadar glukosa darah puasa pada tikus wistar meningkat setelah Induksi aloksan dan kadar glukosa darah puasa pada tikus wistar diabetes melitus yang diinduksi aloksan menurun setelah pemberian latihan fisik selama 4 minggu.

\section{UCAPAN TERIMA KASIH}

Ucapan terima kasih kepada Prof. dr. Rahmatina, B. Herman, PhD, AIF dan DR. Dra. Eti Yerizel, M.S yang telah banyak memberikan bimbingan, bantuan dan motivasi dalam penelitian ini.

\section{DAFTAR PUSTAKA}

1 Alkaff RN, Febrianti, Sri W. Faktor-faktor yang berhubungan dengan diabetes melitus di daerah perkotaan di Indonesia tahun 2007. Medika Islamika Jurnal kedokteran, Kesehatan, dan Keislaman. 2011; 6:8-12.
2 Basu S, Yoffe P, Hills N, Lustig RH. The relationship of sugar to population-level diabetes prevalence: an econometric analysis of repeated cross-sectional Data 2013. PLOS ONE. 2013;8(1):1-8.

3 Whiting DR, Guariguata L, Weil C, Shaw J. IDF diabetes atlas: global estimates of the prevalence of diabetes for 2011 and 2030 . 2011 (diunduh 17 Mei 2013). Tersedia dari: URL: HYPERLINK http://www.ncbi.nlm.nih.gov/ pubmed/22079683

4 Fonseca VA, Kirkman MS, Darsow T, Ratner $\mathrm{RE}$. The American diabetes association diabetes research perspective. Diabetes. 2012;61:133845.

5 Roglic G, Unwin N. Mortality attributable to diabetes: estimates for the year 2010. 2010 (diunduh 16 Mei 2013). Tersedia dari: URL: HYPERLINK http://www.ncbi.nlm.nih.gov/pub med/19914728.

6 PERKENI. Konsensus pengelolaan dan pencegahan diabetes melitus tipe 2 di Indonesia. 2011.

7 Dinas Kesehatan Kota Padang. Profil kesehatan tahun 2011. Edisi 2012. Padang. 2012:15-6.

8 Wapadji S. Pertanyaan pasien dan jawabannya tentang diabetes. Jakarta: Balai Penerbit Fakultas Kedokteran Universitas Indonesia; 2005.

9 Yuriska A. Efek Aloksan terhadap kadar glukosa darah tikus Wistar. (Artikel Karya Tulis IImiah). Semarang: Universitas Diponegoro: 2009.

10 Agunbiade OS, Ojezele OM, Ojezele JO, Ajayi AY. Hypoglycaemic activity of commelinaafricana and ageratumconyzoides in relation to their mineral composition. African Health Sciences, 2012;12:198-203.

11 Amalia M, Gusbakti R, Nazruddin. Pengaruh latihan fisik dengan pemberian suplemen kalsium terhadap kualitas mandibula pada mencit. Ibnu Sina Jurnal Kedokteran dan Kesehatan. 2011;6:16-22.

12 Arulmozhi DK, Veeranjaneyulu A, Bodhankar SL. Neonatal streptozotocin-induced rat model of type 2 diabetes mellitus: a glance. Indian $\mathrm{J}$ 
Pharmacol. 2004;36:217-21.

13 Erwin, et al. Ekspresi insulin pada pankreas mencit yang diinduksi dengan streptozotocin berulang. Jurnal Kedokteran Hewan. 2013;7:97100.

14 Arisman. Buku ajar ilmu gizi obesitas, diabetes melitus, dan dislipidemia. Jakarta: EGC; 2010.

15 Schauer I. Why insulin signals aren't received. 2014 (diunduh 26 januari 2014). Tersedia dari: URL: HYPERLINK http://www.diabetesforecast. org/2014/Jan/why-insulin-signals-arent.html

16 Bittel SL. Organ-based response to exercise in type 1 diabetes. ISRN Endocrinology. 2012;1-2.

17 Farmer K, Huang $\mathrm{HH}$, Jill W, Katie $\mathrm{Y}$, Marry $\mathrm{P}$, Douglas EW, et al. Exercise increases insulin content and basal secretion in pancreatic islets in type 1 diabetic mice. Experimental Diabetes Research. 2011;1-9.

18 Lascar N, Kennedy A, Jackson N. Exercise to preserve beta cell function in recent-onset type 1 diabetes melitus-a study protocol for a pilot randomized controlled trial. Trials; 2013.

19 Zeqiri S, Ylli A, Zeqiri N. The effect of physical activiy in glycemia in patients with diabetes melitus. 2007 (diunduh 26 Januari 2014). Tersedia dari: URL: HYPERLINK http:/www.ncbi. nlm.nih. gov/pubmed/18232276

20 Hadiyanti. Kadar glukosa darah mencit diabetes melitus paska pemberian model latihan isometrik. (Artikel Karya Tulis IImiah). Surabaya: Universitas Airlangga; 2012. 